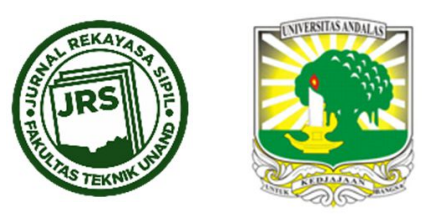

\title{
KUAT TEKAN DAN POROSITAS MORTAR SERBUK KARET PADA SUHU TINGGI
}

\author{
KINGKIN DWI PRATIWI ${ }^{1}$, DIAH WIDYA ${ }^{2}$, ZULFIKAR DJAUHARI ${ }^{3}$, \\ MONITA OLIVIA ${ }^{4}$
${ }^{1}$ Magister Teknik Sipil, Jurusan Teknik Sipil, Fakultas Teknik, Universitas Riau (kingkin.dwipratiwi@grad.unri.ac.id)
${ }^{2}$ Teknik Sipil Jurusan Teknik Sipil, Fakultas Teknik, Universitas Riau (diah.widya@student.unri.ac.id)
3Jurusan Teknik Sipil, Fakultas Teknik, Universitas Riau (zulfikar.djauhari@lecturer.unri.ac.id) \\ ${ }^{4}$ Jurusan Teknik Sipil, Fakultas Teknik, Universitas Riau (corresponding author $₫$ : monita.olivia@lecturer.unri.ac.id)
}

Naskah diterima : 17 Maret 2019. Disetujui: 28 Mei 2019. Diterbitkan : 27 Mei 2019

\section{ABSTRAK}

Serat karet dari ban bekas dapat digunakan sebagai bahan pengganti agregat kasar, agregat halus dan bahan tambah pada mortar dan beton karena memiliki sifat fleksibel sehingga dapat meningkatkan kelenturan dan daktilitas beton serta belum banyak dimanfaatkan sebagai bahan bernilai tinggi. Pada penelitian ini serbuk karet dengan ukuran lebih kecil dari serat karet dari olahan ban bekas pada industri vulkanisir ban digunakan sebagai bahan tambah untuk meningkatkan ketahanan mortar pada suhu tinggi. Serbuk ban bekas yang digunakan berupa partikel kecil dengan variasi sebesar $0 \%$, $2,5 \%$, dan $5 \%$ dari berat semen. Benda uji berupa mortar ukuran 50x50x50mm yang dirawat selama 28 dari dalam air, kemudian dibakar dalam oven tungku (furnace) dengan suhu bervariasi yakni $250^{\circ} \mathrm{C}, 500^{\circ} \mathrm{C}$ dan $750^{\circ} \mathrm{C}$ selama 1 jam. Mortar yang dirawat pada suhu ruang dijadikan sebagai kontrol atau pembanding. Setelah itu dilakukan pengujian kuat tekan dan porositas semua benda uji pada umur 28 hari. Hasil pengujian menunjukkan bahwa mortar dengan penggunaan serbuk karet dapat meningkatkan kuat tekan mortar yang terpapar suhu tinggi. Kuat tekan tertinggi sebesar 15,92 MPa dihasilkan oleh mortar serbuk karet dengan persentase $5 \%$ setelah dibakar pada suhu $500^{\circ} \mathrm{C}$. Peningkatan kuat tekan sebesar $31.66 \%$ tersebut dibanding mortar tanpa serbuk karet menunjukkan bahwa semakin besar persentase serbuk karet, maka akan semakin tinggi ketahanan mortar pada suhu tinggi. Porositas mortar terus mengalami penurunan dengan peningkatan persentase serbuk karet, dengan porositas terkecil adalah mortar serbuk karet $5 \%$ yang dibakar pada suhu $500^{\circ} \mathrm{C}$. Berdasarkan penelitian ini dapat disimpulkan bahwa secara umum serbuk karet dapat meningkatkan kuat tekan dan mengurangi porositas mortar pada suhu $500^{\circ} \mathrm{C}$.

Kata kunci : Ban bekas, Mortar, Porositas, Serbuk karet, Suhu tinggi

\section{PENDAHULUAN}

Kebakaran dapat mengakibatkan kerusakan pada bangunan dengan cepat, tidak terkecuali pada struktur beton. Reaksi pembakaran merupakan merupakan reaksi kimia oksigen dengan bahan mudah terbakar yang menghasilkan panas (Ahmad, 2001). Beton pada dasarnya tidak mampu menahan panas lebih dari $250^{\circ} \mathrm{C}$ (Tjokrodimuljo, 1996). Pada

DOI : https://doi.org/10.25077/jrs.15.1.57-65.2019

Attribution-NonCommercial 4.0 International. Some rights reserved 
kebakaran atau pemaparan suhu tinggi di sekitar permukaan beton dapat terjadi retakan akibat pemuaian air yang hilang dalam mortar. Oleh karena itu mortar yang terpapar suhu tinggi baik secara radiasi maupun konveksi akan mengakibatkan perubahan kinerja akibat perubahan sifat material dalam level mikrostruktur. Akibat suhu tinggi atau panas, beton akan mengalami retak, terkelupas (spalling), dan kehilangan kekuatan. Kehilangan kekuatan terjadi karena perubahan komposisi kimia secara bertahap pada pasta semennya (Suku et al. 2017). Hasil penelitian Atmaja et al. (2006) menunjukkan bahwa mutu beton dan lama pembakaran mempengaruhi kekuatan beton setelah terpapar suhu tinggi dalam oven. Penurunan sifat mekanis seperti kuat tekan dan modulus elastisitas terjadi setelah beton dibakar meskipun secara umum beton lebih tahan terhadap suhu tinggi dibanding material lain. Penelitian Bayuasri et al. (2006) membuktikan bahwa semakin tinggi mutu beton maka penurunan kekuatan setelah dibakar akan lebih besar dibandingkan beton dengan mutu rendah karena faktor air semen yang kecil dan membuat beton lebih mudah mengalami hidrasi.

Pada umumnya untuk mengurangi kerusakan bangunan akibat kebakaran dapat digunakan material tahan kebakaran yang memiliki kualitas tinggi seperti baja dan beton. Untuk mengurangi retak dan kehilangan kekuatan akibat terpapar suhu tinggi dapat ditambahkan beton jenis baru atau menambahkan bahan aditif maupun limbah seperti slag, ban karet bekas, dan abu sawit (Aydin, 2008, Muhammad et al. 2017, Ismail, et al. 2011). Ban bekas merupakan limbah dari roda kendaraan bermotor yang sudah tidak layak pakai dan sulit didaur ulang karena memiliki struktur petrokimia kompleks dan bersifat karsinogen. Kecepatan penumpukan ban bekas di alam yang tidak dimanfaatkan dapat mencemari lingkungan. Di Indonesia limbah ban bekas jarang digunakan, hanya digunakan pada pembuatan kerajinan, tali, sendal dan dijadikan fender atau pelindung dermaga. Limbah ban tidak dapat dibakar karena mengandung bahan berbahaya dan menjadi sumber polusi udara. Pada suhu di atas $322^{\circ} \mathrm{C}$ ban baru dapat terbakar, sehingga ban tidak mudah dimusnahkan dengan cara dibakar (Edeskar, 2004).

Untuk beton atau mortar yang terpapar suhu tinggi atau terbakar, maka pada saat terbakar terjadi hidrasi karena air menguap dan menimbulkan keretakan sehingga berpengaruh pada kekuatan beton. Berdasarkan penelitian terdahulu, penambahan serat ban karet dalam campuran mortar dapat meningkatkan kekuatan dan mencegah keretakan karena karet dapat menurunkan suhu di dalam beton (Sari et al. 2013). Penggunaaan serat ban bekas direkomendasikan utuk meningkatkan ketahanan beton di suhu tinggi, akan tetapi ukurannya yang tidak seragam akan menyebabkan serat tidak terdistribusi dengan baik dalam campuran. Untuk memudahkan pekerjaan pembuatan mortar dan memanfaatkan serbuk karet berukuran kecil yang tidak termanfaatkan maka pada penelitian ini akan dikaji penggunaan serbuk karet dengan persentase $0 \%, 2,5 \%$, dan $5 \%$ sebagai bahan tambah untuk meningkatkan kuat tekan dan menurunkan porositas mortar pada suhu $250^{\circ} \mathrm{C}, 500^{\circ} \mathrm{C}$ dan $750^{\circ} \mathrm{C}$ pada umur 28 hari.

\section{MORTAR BETON}

Mortar merupakan bahan pelapis dinding dan elemen struktur yang umum digunakan dalam bangunan. Mortar didefinisikan berupa campuran material yang terdiri dari bahan perekat, agregat halus dan air dengan komposisi tertentu menurut SNI 03-6825-2002. Mortar yang baik mudah dikerjakan, merekat dengan sempurna, tahan lama, murah, tahan rembesan air, cepat mengering, cepat mengeras dan tidak retak-retak setelah mengering (Tjokrodimuldo, 1996). Berdasarkan SNI 03-6882-2002 dan ASTM C270, mortar diklasifikasikan menjadi beberapa kelas tergantung dari kuat tekan dan lingkungan tempat struktur dibangun. Meskipun umum digunakan sebagai bahan plesteran tetapi mortar perlu 
memiliki kekuatan tinggi, durabilitas tinggi, dan permeabilitas rendah apabila dipakai pada lingkungan agresif seperti lingkungan laut, asam dan suhu tinggi. Mortar dengan karakteristik demikian dihasilkan dari campuran yang menggunakan pozzolan sebagai pengganti semen atau bahan tambah seperti produk komersil silica fume maupun limbah alami serbuk kulit kerang (Fajrin, et al. 2016, Syafpoetri et al. 2018).

Kebakaran dapat mengakibatkan retakan awal pada struktur beton, lalu menimbulkan ledakan yang berbahaya serta dapat menimbulkan korban jiwa serta menghancurkan bangunan. Apabila beton dipanaskan pada suhu di atas 500으, akan terjadi penurunan kekuatan karena proses dekomposisi CSH (Calcium Silicate Hydrate) menjadi CaO dan $\mathrm{SiO}_{2}$ (Suku et al. 2013). Selain itu perubahan suhu tinggi yang sangat drastis dapat mempercepat kerusakan struktur beton. Struktur beton pada saat terbakar dapat menyerap panas sehingga menyebabkan peningkatan suhu berlebihan yang berakibat perubahan pada level mikrostruktur. Pada suhu tertentu stabilitas ikatan produk hidrasi semen rusak disebabkan pemanasan sehingga terjadi pemuaian butiran kerikil (agregat) dan terlepasnya ikatan semen. Penurunan stabilitas ikatan matriks beton akibat suhu tinggi secara tidak langsung memperbesar porositas dan menurunkan kuat tekan beton.

Beton yang menggunakan karet bekas tersebut dapat berkontribusi dalam konstruksi berkelanjutan karena ketersediaan bahan baku melimpah berupa limbah kendaraan bermotor yang terus diproduksi secara besar-besaran. Penggunaan limbah ban bekas dalam skala besar memerlukan proses efisien dan tidak mengotori lingkungan seperti menjadi shock absorber pondasi rumah sederhana tahan gempa (Sarfors, 2011), maupun sebagai pengganti agregat kasar, agregat halus dan bahan tambah dalam beton (Ganjian et al. 2009, Gupta et al. 2014). Jenis limbah ban bekas dapat dilihat pada Gambar 1. Hasil pengolahan di industri vulkanisir ban bekas dapat berupa kepingan (chip), serat (fibre), remah (crumb), dan serbuk (particle) karet yang dapat dimanfaatkan untuk berbagai kebutuhan pada beton. Kepingan ban dapat digunakan sebagai agregat kasar dan halus, sedangkan serat ban berfungsi sebagai penambah kelenturan matriks. Remah dan serbuk karet berpotensi digunakan pada mortar untuk membantu meningkatkan kekedapan termasuk daya tahan pada suhu tinggi (Thomas dan Gupta, 2016).

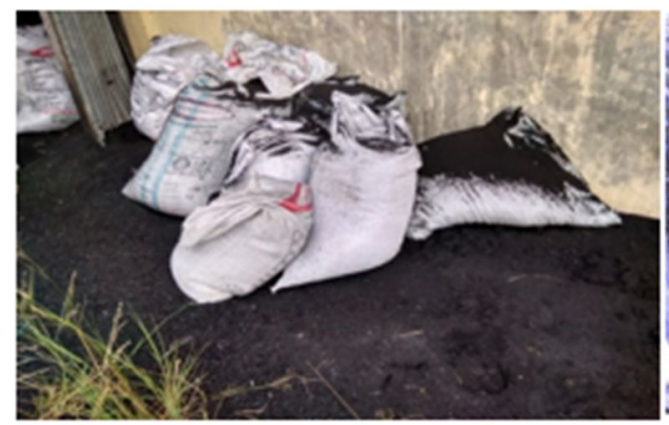

(a)

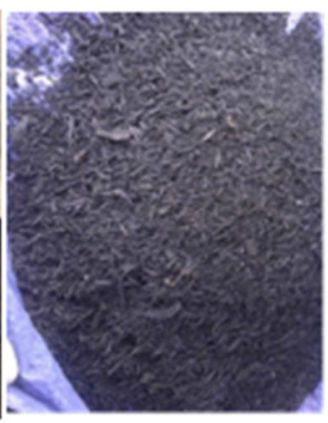

(b)

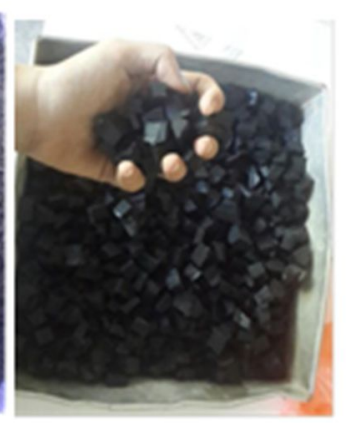

(c)

Gambar 1. Limbah ban karet (a) Serat Karet di Pabrik Ban Vulkanisir, (b) Crumb Rubber (Putra, 2015), (c) Tire Chips (Putra, 2015).

Hasil review literatur mengenai ban bekas Thomas dan Gupta (2016) menunjukkan bahwa beton menggunakan limbah ban karet mengurangi kuat tekan, meningkatkan daya tahan terhadap abrasi, penurunan absorpsi, meningkatkan ketahanan terhadap serangan asam dan klorida. Menurut Wang et al. (2013), kekuatan beton dan mortar yang dicampur dengan karet berasal dari kekakuan serat ban karena semakin tinggi kekakuan ban, maka semakin 
besar kekuatan beton dan mortar. Penambahan serat karet sebagai bahan tambah untuk beton tahan suhu tinggi dapat meningkatkan nilai kuat tekan, karena ketika beton normal mengalami kebakaran maka air yang ada di dalam beton akan membentuk lorong-lorong kecil dan pada akhirnya akan menguap menimbulkan keretakan yang menyebabkan kekuatan beton menurun. Sehingga dengan penambahan ban karet dalam campuran beton, ketika terjadi kebakaran dapat menggantikan air yang hilang dan kemudian mencegah keretakan yang timbul akibat kekeringan (Sari et al. 2013). Hasil penelitian Sari et al. (2013) membuktikan bahwa persentase karet dalam campuran turut mempengaruhi kekuatan mortar selain suhu. Pemakaian ban karet sebesar $5 \%$ dari berat semen menaikkan nilai kuat tekan mortar sebesar 51,7\%. Pada umur 28 hari kekuatan beton menjadi $473,44 \mathrm{~kg} / \mathrm{cm}^{2}$, dibandingkan terhadap mortar tanpa bahan tambah. Ketika terpapar suhu tinggi, mortar dengan campuran ban karet sebesar 5\% menunjukkan bahwa suhu di dalam beton lebih rendah jika dibandingkan dengan suhu di permukaan beton sehingga mengurangi resiko terjadinya keretakan.

\section{METODOLOGI PENELITIAN}

Semen yang digunakan adalah semen tipe I OPC (Ordinary Portland Cement) produksi PT. Semen Padang, Sumatera Barat. Agregat halus berasal dari Kampar, Riau. Ukuran butiran (gradasi) yang dipakai adalah lewat saringan 1,190 mm (saringan No.16). Hasil pengujian karateristik agregat halus meliputi berat jenis sebesar 2,65, modulus kehalusan sebesar 4,07, kadar air sebesar 1,42\% dan kadar lumpur sebesar 0,95\%. Serbuk karet diperoleh dari industri vulkanisir ban di kota Pekanbaru. Pengujian karakteristik serbuk karet dilakukan untuk mengetahui senyawa yang terkandung di dalamnya (Tabel 1). Hasil pengujian pada Tabel 1 menunjukkan bahwa serbuk karet mengandung silika ( $\mathrm{Si}$ ) sebesar 2,21\% dan sulfur yang dapat mengubah karet menjadi lebih elastis. Kedua senyawa ini berguna untuk optimalisasi kinerja ban sehingga tahan terhadap suhu tinggi. Hal ini yang mendasari penggunaan serbuk ban karet sebagai bahan campuran mortar terhadap suhu tinggi selain suhu yang dibutuhkan untuk penguraian ban sebesar $322^{\circ} \mathrm{C}$ (Edeskar, 2004).

Tabel 1. Data Fisik Serbuk Karet.

\begin{tabular}{llll}
\hline $\begin{array}{l}\text { Parameter } \\
\text { Uji }\end{array}$ & Satuan & Hasil Analisa & Metoda Uji \\
\hline $\mathrm{S}$ & $\%$ & 0,02 & SNI 15-2049-2004 \\
\hline $\mathrm{Zn}$ & $\%$ & 1,62 & ASTM C1301-95 (2001) \\
\hline $\mathrm{Mg}$ & $\%$ & 0,02 & ASTM C1301-95(2001) \\
\hline $\mathrm{Al}$ & $\%$ & 0,12 & SNI 15-2049-2004 \\
\hline $\mathrm{Si}$ & $\%$ & 2,21 & SNI 15-2049-2004 \\
\hline
\end{tabular}

Benda uji berupa kubus berukuran 50x50x50mm. Serbuk karet digunakan sebagai bahan tambah sebesar $0 \%, 2,5 \%$, dan $5 \%$ dari berat semen. Komposisi mortar yang digunakan mengacu pada SNI 06-6825-2002, yakni untuk setiap benda uji digunakan semen, pasir, air dan serbuk karet pada Tabel 2.

Tabel 2. Bahan Penyusun Campuran Mortar.

\begin{tabular}{llll}
\hline $\begin{array}{l}\text { Persentase Serbuk } \\
\text { Karet }\end{array}$ & $\mathbf{0 \%}$ & $\mathbf{2 , 5 \%}$ & $\mathbf{5 \%}$ \\
\hline Semen $(\mathrm{g})$ & 500 & 500 & 500 \\
\hline Pasir $(\mathrm{g})$ & 1375 & 1375 & 1375 \\
\hline Air $(\mathrm{ml})$ & 242 & 242 & 242 \\
\hline Serbuk karet $(\mathrm{g})$ & 0 & 12,5 & 25 \\
\hline
\end{tabular}


Proses pembuatan benda uji dimulai dengan menimbang material penyusun mortar berdasarkan komposisi pada Tabel 2. Prosedur pembuatan mortar terlebih dahulu memasukkan serbuk karet, kemudian menuangkan air ke dalam cawan pengaduk, lalu memasukan semen secara perlahan-lahan, setelah itu kedua bahan dibiarkan dalam cawan pengaduk selama 30 detik. Kemudian campuran diaduk kembali selama 30 detik dengan kecepatan putaran mesin pengaduk sebesar $140 \mathrm{ffl} 5$ putaran per menit atau kecepatan nomor 1. Selanjutnya masukkan pasir sedikit demi sedikit ke dalam cawan yang telah berisi semen dan air lalu diaduk kembali selama 30 detik. Selanjutnya pengadukan dilanjutkan kembali selama 30 detik pada kecepatan $285 \mathrm{ffl} 10$ putaran per menit atau kecepatan nomor 2 . Hentikan pengadukan, lalu bersihkan campuran yang terdapat pada pinggiran cawan tersebut selama 15 detik. Mortar didiamkan selama 75 detik dalam cawan pengaduk yang ditutup. Pengadukan diulang kembali selama 60 detik dengan kecepatan pengadukan $285 f f l 10$ putaran per menit.
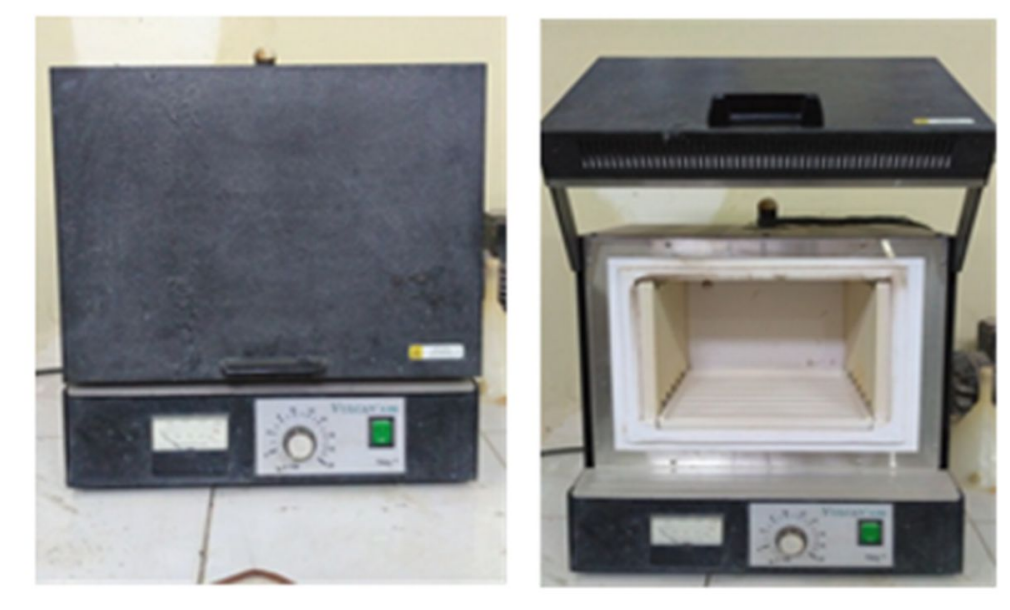

Gambar 2. Oven furnace

Campuran mortar dimasukkan ke dalam cetakan kubus ukuran 50x50x50mm. Pengisian cetakan dilakukan sebanyak 2 lapis dan setiap lapis harus dipadatkan sebanyak 32 kali dengan 4 kali putaran dalam 10 detik. Setelah didiamkan selama 24 jam, cetakan mortar dibuka dan benda uji dikeluarkan. Proses perawatan dilakukan dengan merendam benda uji selama 28 hari dalam air. Benda uji lalu terpapar suhu $250^{\circ} \mathrm{C}, 500^{\circ} \mathrm{C}$ dan $750^{\circ} \mathrm{C}$ selama 60 menit di dalam oven furnace yang dapat dilihat pada Gambar 3. Pengujian kuat tekan berdasarkan SNI 06-6825-2002 dan pengujian porositas setelah dibakar mengacu pada ASTM C642 dilakukan pada benda uji.

\section{HASIL DAN PEMBAHASAN}

\subsection{Kuat Tekan}

Kuat tekan pada suhu ruang dan kuat tekan mortar setelah terpapar suhu $250^{\circ} \mathrm{C}, 500^{\circ} \mathrm{C}$, dan $750^{\circ} \mathrm{C}$ dapat dilihat pada Gambar 3. 


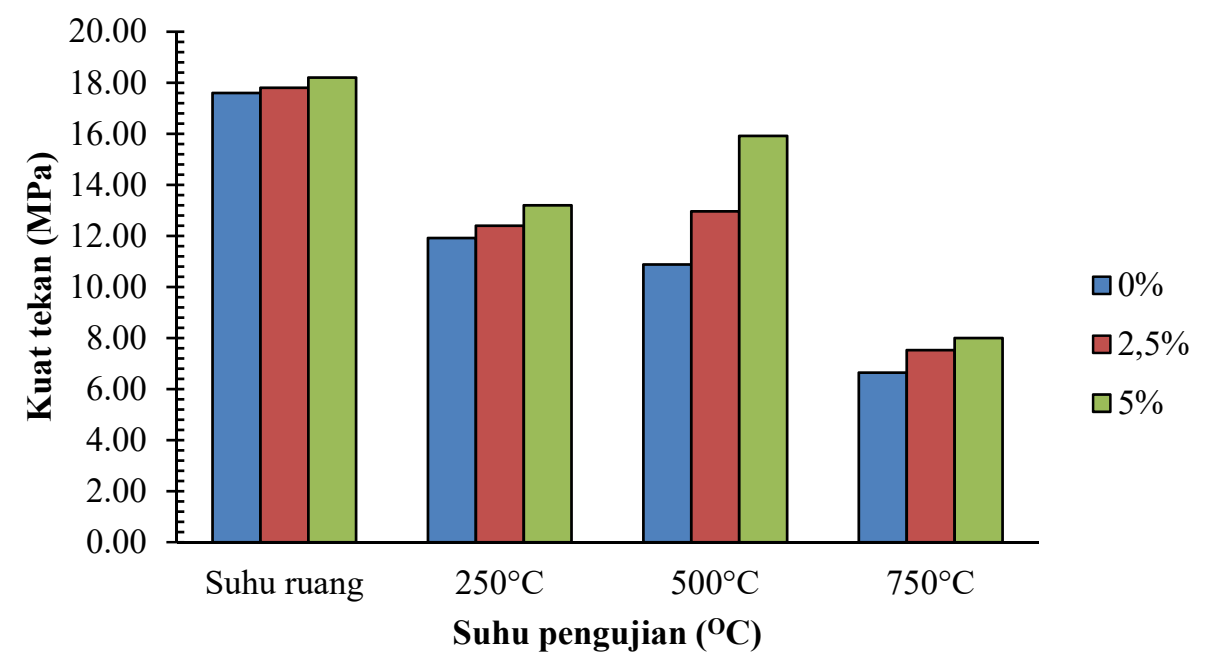

Gambar 3. Perubahan kuat tekan mortar serbuk karet pada berbagai suhu pengujian pada umur 28 hari.

Pada umumnya kuat tekan menurun seiring dengan peningkatan suhu pengujian. Setelah mortar diuji pada suhu $250^{\circ} \mathrm{C}$ terjadi penurunan kuat tekan sebesar $27,47-32,27 \%$ dari kuat tekan pada suhu ruang. Penurunan tertinggi dibandingkan dengan mortar pada suhu ruang terjadi saat mortar telah terpapar suhu $750^{\circ} \mathrm{C}$ yakni berkisar antara 56,05\%-62,67\%. Hal ini menunjukkan bahwa semakin tinggi suhu pengujian, maka akan semakin besar pengurangan kekuatan mortar. Pada mortar terkena suhu $250^{\circ} \mathrm{C}$ terjadi proses penguapan air tetapi proses hidrasi masih terjadi, sehingga kekuatan mortar mengalami penurunan lebih dari $25 \%$. Sedangkan pada mortar terpapar suhu $750^{\circ} \mathrm{C}$ akan mengalami kerusakan ikatan produk hidrasi lanjutan CSH (Calcium Silicate Hydrate) (Castellote et al. 2004) dan penurunan kuat tekan lebih dari 50\% kekuatan awal pada suhu ruang.

Pada Gambar 3 dapat dilihat bahwa kuat tekan mortar terpapar suhu tinggi meningkat dengan penambahan serbuk karet dalam campuran. Peningkatan kuat tekan berkisar antara $4,03-10,74 \%$ dibanding mortar tanpa serbuk karet pada suhu $250^{\circ} \mathrm{C}$. Peningkatan kuat tekan tertinggi sebesar 46,32\% dihasilkan oleh mortar 5\% serbuk karet setelah terpapar suhu $500^{\circ} \mathrm{C}$. Penambahan serbuk karet sebesar $5 \%$ menyebabkan penurunan kekuatan sebesar $12,53 \%$ dari mortar dengan persentase yang sama dirawat pada suhu ruang. Hal ini menunjukkan bahwa penambahan serbuk karet sebesar 5\% dapat membantu mengurangi penguapan air dalam mortar dan mencegah kerusakan lebih lanjut ikatan-ikatan produk hidrasi dengan cara mengubah karet menjadi material plastis pengisi pori sehingga dapat mempertahankan integritas mortar saat dibakar pada suhu $500^{\circ} \mathrm{C}$. Ban bekas memiliki ikatan kimia yang kuat sehingga membutuhkan suhu lebih tinggi dari $322^{\circ} \mathrm{C}$ agar dapat terbakar (Edeskar, 2004) sehingga serbuk karet baru efektif meningkatkan ketahanan mortar pada suhu sekitar $500^{\circ} \mathrm{C}$. Hasil penelitian Sari et al. (2013) juga menunjukkan bahwa kuat tekan tertinggi dihasilkan oleh mortar dengan campuran ban karet sebesar $5 \%$. Berdasarkan hasil penelitian ini maka penambahan serbuk karet sebesar $5 \%$ dapat direkomendasikan untuk meningkatkan ketahanan mortar pada suhu tinggi $500^{\circ} \mathrm{C}$.

\subsection{Porositas}

Nilai porositas mortar atau beton menunjukkan jumlah persentase ruang kosong antara fase material di dalam mortar atau beton. Secara umum kuat tekan berbanding terbalik dengan 
nilai porositas untuk mortar dan beton dari semen OPC. Berdasarkan hasil pengujian mortar serbuk karet dengan berbagai persentase serbuk dan suhu, pada Gambar 5 dapat dilihat bahwa porositas mortar meningkat seiring dengan peningkatan suhu pengujian. Porositas mortar meningkat pada suhu $250^{\circ} \mathrm{C}$, lalu menurun sedikit dan kemudian mengalami peningkatan tajam setelah mortar terkena suhu $750^{\circ} \mathrm{C}$. Peningkatan porositas tertinggi sebesar $118,53 \%$ dihasilkan oleh mortar dengan persentase serbuk karet 2,5\% terpapar suhu $750^{\circ} \mathrm{C}$, sedangkan peningkatan porositas terendah dihasilkan oleh mortar tanpa serbuk karet sebesar $8,91 \%$ pada suhu $500^{\circ} \mathrm{C}$. Peningkatan porositas mortar umumnya karena penguapan air yang meninggalkan ruang-ruang kosong dalam matriks dan perlemahan ikatan produk hidrasi sehingga rongga dalam mortar terus bertambah. Semakin tinggi suhu, maka kerusakan semakin besar dan persentase porositas pada mortar akan meningkat tajam. Hal ini dapat dibuktikan dengan semakin hilangnya ikatan CSH pada suhu di atas $550^{\circ} \mathrm{C}$ dan penurunan kualitas mortar (Castellote et al. 2004, Joedono, 2007). Berdasarkan hasil penelitian Putri et al. (2015) dan Afrian et al. (2016), mortar yang mengalami kerusakan setelah terpapar suhu tinggi umumnya mempunyai berat satuan rendah karena sangat porous. Ray (2005) memperkuat alasan tersebut karena setelah mengering akibat peningkatan suhu maka pori yang berisi udara dan air berhubungan dan membentuk kapiler, hal ini mengakibatkan mortar bersifat mudah slip, daya ikat berkurang dan tembus air.

Pada Gambar 4 dapat dilihat bahwa persentase serbuk karet dalam campuran mortar sangat mempengaruhi penurunan nilai porositas. Penurunan porositas terbesar yakni $21,32 \%$ dihasilkan oleh mortar serbuk karet 5\% pada suhu ruang. Perubahan porositas sangat signifikan sebesar $15,22 \%$ terjadi setelah mortar dengan 5\% serbuk karet terpapar suhu $750^{\circ} \mathrm{C}$. Penurunan porositas terendah diamati pada mortar dengan serbuk karet $2,5 \%$ sebesar $1,14 \%$ pada suhu $500^{\circ} \mathrm{C}$. Pada suhu yang sama, mortar dengan $5 \%$ serbuk karet menunjukkan penurunan porositas rendah sebesar 4,82\%. Secara umum hal ini menunjukkan bahwa penambahan serbuk karet dapat menurunkan porositas mortar meskipun suhu pengujian semakin ditingkatkan. Penurunan porositas ini memperlihatkan bahwa serbuk karet sebesar 5\% dapat meningkatkan ketahanan mortar pada suhu tinggi. Serbuk karet berubah menjadi material liquid dari solid jika terpapar suhu di atas $250^{\circ} \mathrm{C}$, sehingga karet liquid dapat mengisi rongga pori dan menyebabkan persentase porositas semakin berkurang. Meski demikian, penambahan serbuk karet hanya akan efektif jika mortar terpapar suhu sekitar $500^{\circ} \mathrm{C}$.

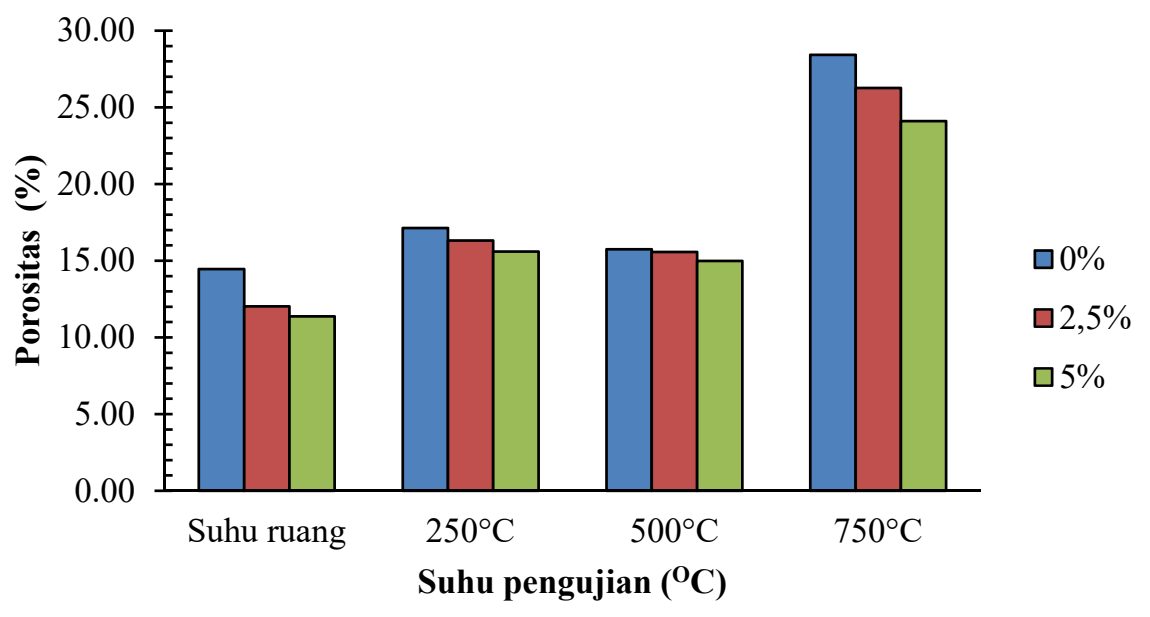

Gambar 4. Perubahan porositas mortar serbuk karet pada berbagai suhu pengujian pada umur 28 hari. 
Gambar 5 menunjukkan hubungan antara porositas dengan kuat tekan mortar yang terpapar suhu ruang dan suhu tinggi. Berdasarkan hubungan tersebut dapat dilihat bahwa porositas berbanding terbalik dengan kuat tekan mortar. Semakin tinggi kuat tekan maka porositas akan semakin menurun meskipun persentase serbuk karet turut mempengaruhi kekedapan mortar saat terkena suhu tinggi. Korelasi kuat tekan dan porositas mortar serbuk karet dan mortar tanpa serbuk karet berbanding lurus dengan $\mathrm{R}^{2}=0,83793$.

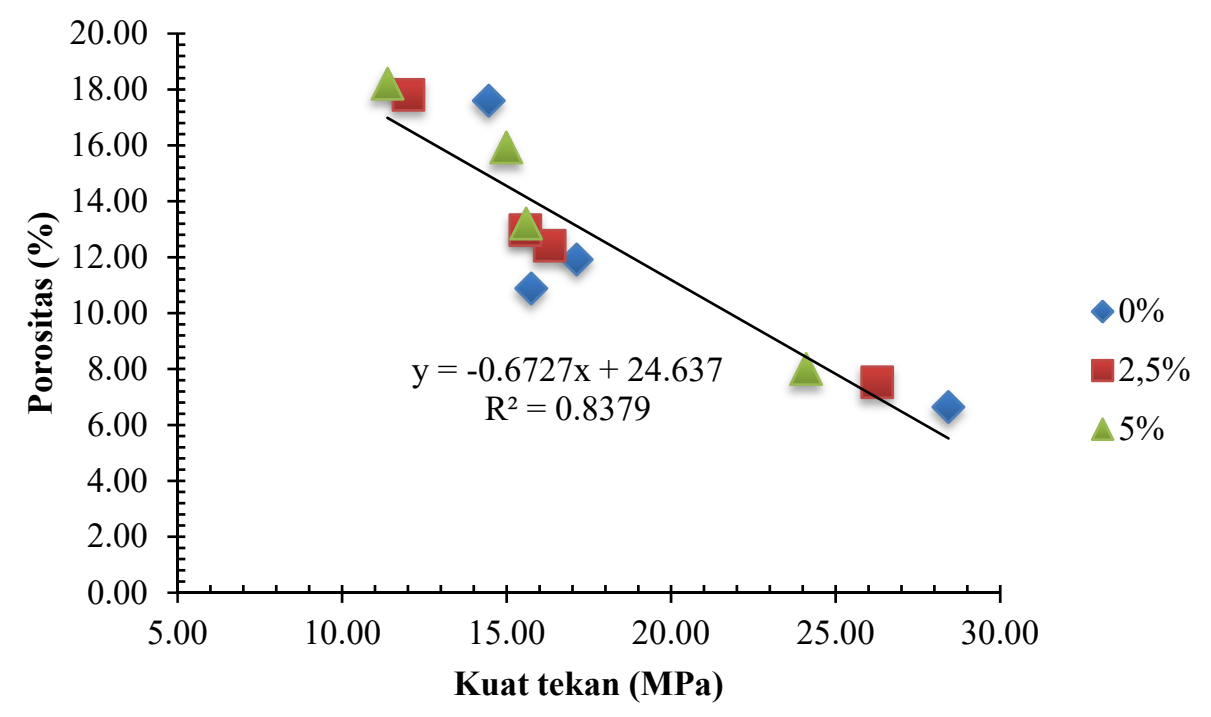

Gambar 5. Hubungan antara kuat tekan dan porositas mortar tanpa dan menggunakan serbuk karet pada umur 28 hari

\section{SIMPULAN DAN SARAN}

Pada penelitian ini, serbuk karet digunakan sebagai bahan tambah pada campuran mortar dengan persentase $2,5 \%$ dan $5 \%$ untuk meningkatkan ketahanan terhadap suhu tinggi pada suhu $250^{\circ} \mathrm{C}, 500^{\circ} \mathrm{C}$, dan $750^{\circ} \mathrm{C}$. Sebagai pembanding digunakan mortar tanpa tambahan serbuk karet dan pengujian pada suhu ruang. Hasil penelitian menunjukkan bahwa peningkatan suhu secara umum akan menurunkan kuat tekan dan meningkatkan porositas mortar dengan atau tanpa serbuk karet. Peningkatan kuat tekan dan penurunan porositas terbaik dihasilkan oleh mortar dengan $5 \%$ serbuk karet terpapar suhu $500^{\circ} \mathrm{C}$. Nilai porositas mortar berbanding terbalik dan memiliki korelasi berbanding lurus sebesar = 0,83793. Berdasarkan hasil pengujian dapat disimpulkan bahwa penambahan serbuk karet dapat meningkatkan ketahanan mortar terpapar suhu tinggi.

\section{UCAPAN TERIMAKASIH}

Penulis ingin mengucapkan terima kasih kepada rekan-rekan Final Year Project Batch 6 dan Tesis Batch 2 atas bantuan dalam pengerjaan dan pengujian di Laboratorium Struktur, Fakultas Teknik Universitas Riau.

\section{DAFTAR PUSTAKA}

Afrian, M., Djauhari, Z., Olivia, M. (2016). Ketahanan Mortar Abu Sekam Padi pada Suhu Tinggi. Prosiding Seminar ACE. Seminar Nasional Andalas Civil Engineering 2016, 22-23 Oktober 2016, Padang.

Ahmad, I.A. (2000). Tinjauan Kelayakan Balok Beton Bertulang Pascabakar secara Analisis dan Eksperimen (Tesis). Yogyakarta: Program Pasca Sarjana Universitas Gadjah Mada. 
Atmaja, F.R., Triana, D., Ujianto, R. (2017). Struktur Beton Pasca Kebakaran Terhadap Kuat Tekan dan Karakteristik Beton. Jurnal Civtech Teknik Sipil Universitas Serang Raya, 1(1), 1-13.

Aydin, S. (2008). Development of a High-Temperature-Resistant Mortar by using Slag and Pumice. Fire Safety Journal, 43, 610-617.

Bayuasri, T., Indarto, H., Antonius. (2006). Perubahan Perilaku Mekanis Beton akibat Temperatur Tinggi. Pilar, 15(2), 117-126.

Castellote, M., Alonso, C., Andrade, C., Xavier T., Javier, C. (2004). Composition and Microstructural Changes of Cement Pastes Upon Heating. Cement Concrete Research, 34, 1633-1644.

Edeskar, T. (2004). Technical and Environmental Properties of Tyre Shreds Focusing on Ground Engineering Applications. Technical Report. Lulea: Lulea University of Technology.

Fajrin, J., Pathurahman, Pratama, L.G. (2016). Aplikasi Metode Analysis of Variance (ANOVA) untuk Mengkaji Pengaruh Penambahan Silica Fume terhadap Sifat Fisik dan Mekanik Mortar. Jurnal Rekayasa Sipil, 12(1), 11-23. doi:https://doi.org/10.25077/jrs.13.2.79-90.2017

Ganjian, E., Khorami, M., Maghsoudi, A.A. Scrap-tyre-rubber Replacement for Aggregate and Filler in Concrete. Construction and Building Materials, 23, 1828-1836.

Gupta, T., Chaudhary, S., Sharma, R.K. (2014). Assessment of Mechanical and Durability Properties of Concrete Containing Waste Rubber Tire as Fine Aggregate. Construction and Building Materials, 73, 562-574.

Ismail, M., Ismail, M.E., Muhammad, B. (2011). Influence of Elevated Temperature on Physical and Compressive Strength Properties of Concrete Containing Palm Oil Fuel Ash. Construction and Building Materials, 25, 2358-2364.

Joedono, N. (2007). Mechanical Properties of After-Fire Concrete with Rice Husk Ash (RHA) as an Additional Material. Jurnal Teknik Sipil dan Perencanaan, 9(1), 1-8.

Muhammad, M.A., Abdullah, W.A., Abdul-Kadir, M.R. (2017). Post-Fire Mechanical Properties of Concrete Made with Recycled Tire Rubber as Fine Aggregate Replacement. Sulaimani Journal for Engineering Sciences, 4(5), 74-85.

Putra, L.O. (2015). Perilaku Lentur Beton yang menggunakan Limbah Ban sebagai Agregat (Tugas Akhir). Makassar: Universitas Hasanuddin.

Putri, N.D., Djauhari, Z., Olivia, M. (2015). Kuat Tekan, Porositas dan Sorptivity Mortar dengan Bahan Tambah Gula Aren pada Suhu Tinggi. Prosiding Seminar ACE. Seminar Nasional Andalas Civil Engineering 2015, 13 Agustus 2015, Padang.

Ray, N. (2005). Pengaruh WC Ratio pada Perubahan Perilaku Beton Mutu Normal pada Temperatur Tinggi Pasca Kebakaran. Jurnal Rekayasa Perencanaan, 2(1), 1-14.

Sarfors, I. (2011). Used tire as base isolator tire for earthquake resistant houses. Jurnal Rekayasa Sipil, 7(1), 37-44. doi:https://doi.org/10.25077/jrs.7.1.37-44.2011

Sari, D.W., Ariefyanto, F., Gunawan, H., Olivia, M. (2013). Kinerja Beton Berserat Karet pada Suhu Tinggi. Jurnal Sains dan Teknologi, 12(1), 12-15.

Suku, Y.L., Manteiro, FX. M., Nelo, D. (2013). Perubahan Perilaku Kuat Tekan dan Tarik Belah pada Beton akibat Pemanasan. Majalah Ilmiah Indikator, 16(2), 20-29.

Syafpoetri, N.A., Djauhari, Z., Olivia, M. (2018). Karakteristik Mortar dengan Campuran Abu Kerang Lokan dalam Rendaman NaCl. Jurnal Rekayasa Sipil, 14(1), 63-71. doi:https://doi.org/10.25077/jrs.14.1.63-72.2018

Thomas, B.S., Gupta, R.C. (2016). A Comprehensive Review on the Applications of Waste Tire Rubber in Cement Concrete. Renewable and Sustainable Energy Reviews, 54, 1323-1333.

Tjokrodimuljo, K. (1996). Teknologi Beton. Yogyakarta: Biro Penerbit Teknik Sipil Universitas Gadjah Mada.

Wang, H-Y., Chen, B.T., Wu, Y-W. (2013). A Study of the Fresh Properties of Controlled Low-strength Rubber Lightweight Aggregate Concrete (CLSRLC). Construction and Building Materials, 41, 526-531. 